Nevşehir Bilim ve Teknoloji Dergisi Cilt 4(2) 9-25 2015

DOI: $10.17100 /$ nevbiltek.210965

URL: http://dx.doi.org/10.17100/nevbiltek.210965

\title{
Domates, Patlıcan ve Kavun Genotiplerinin Kuraklığa Dayanım Durumlarını Belirlemeye Yönelik Olarak İncelenen Özellikler Arasındaki İlişkiler
}

\author{
Sevinç Kıran ${ }^{1 *}$, Şebnem Kuşvuran ${ }^{2}$, Fatma Özkay ${ }^{1}$, Ş. Şebnem Ellialtıoğlu ${ }^{3}$ \\ ${ }^{1}$ Toprak Gübre ve Su Kaynakları Araştırma Enstitüsü, Ankara \\ ${ }^{2}$ Çankırı Karatekin Üniversitesi, Kızılırmak Meslek Yüksekokulu, Çankırı \\ ${ }^{3}$ Ankara Üniversitesi, Ziraat Fakültesi, Bahçe Bitkileri Bölümü, Ankara \\ Öz
}

Kuraklık stresine dayanım seviyeleri belirlenmek üzere seçilen dörder adet domates (TR-68516, Rio Grande, TR-63233, TR-63233, H-2274), patlican (Mardin-Kızıltepe, Burdur-Merkez, Artvin-Hopa, Kemer) ve kavun (Midyat, Şemame, Yuva, Ananas) genotipinde; stres koşulları altındaki bitki yaş ve kuru ağırlığı, yaprak alanı, nispi nem, yaprak su potansiyeli, klorofil, Ca, Zn, Mn ve Fe içeriği ile SOD, CAT, GR ve APX enzim aktiviteleri arasındaki istatistiksel ilişkiler araştırılmıştır. Üç türde yapılan korelasyon analizleri, skala değerlendirmesinin kuraklığa dayanımı gösteren önemli bir parametre olduğunu göstermiştir. Stres altındaki bitkilerde, bitki yaş ve kuru ağırlığı ile yaprak alanı ve nispi nem oranı arasında; ayrıca skala değeri ile stoma iletkenliği arasında negatif bir korelasyon ortaya çıkmıştır. Kuraklık stresi bitkilerdeki MDA miktarında ve Süperoksit dismutaz (SOD), glutatyon redüktaz (GR), askorbat peroksidaz (APX) ve katalaz (CAT) enzim aktivitelerinde artışa neden olmuştur. CAT ve GR enzim aktiviteleri ile skala arasında yüksek düzeyde bir negatif korelasyon olduğu görülmüştür.

Anahtar Kelimeler: Kuraklık, tuzluluk, tolerans, genotip, patlıcan, domates, kavun

\section{Determination of Relationship among Different Parameters for Evaluated Drought Resistance in Tomatoes, Eggplant and Melon Genotypes}

\begin{abstract}
In this research, tomato (TR-68516, Rio Grande, TR-63233, TR-63233, H-2274), eggplant (Mardin-Kiziltepe, Burdur-Merkez, Artvin-Hopa, Kemer), and melon (Midyat, Şemame, Yuva, Ananas) genotypes which were chosen to determine their tolerance levels against drought, were evaluated for fresh and dry weights, leaf area, relative humidity, leaf water potential, chlorophyll content, $\mathrm{Ca}, \mathrm{Zn}, \mathrm{Mn}$ and Fe contents, besides SOD, CAT, GR, and APX enzyme activity under stress conditions. The correlation analysis were determined as an important parameter indicating drought resistance in the three vegetable species. Under stress condition, a positive correlation was determined between leaf area and relative humidity in the means of fresh and dry weights. However, a negative correlation was shown between scala and stomatal conductance. Drought stress was caused increasing in MDA content, superoxide dismutase (SOD), glutathione reductase (GR), ascorbate peroxidase (APX) and catalase (CAT) enzyme activities in all of the genotypes. The high level of the negative correlation was observed between the CAT, GR enzyme activities, and scala.
\end{abstract}

Keywords: Drought, salinity, tolerance, genotype, eggplant, tomato, melon

\footnotetext{
*e-mail: sevinc.kiran@gthb.gov.tr
} 


\section{Kıran S., Kuşvuran Ş., Özkay F., Ellialtıŏglu ŞŞ.}

\section{Giriş}

Kuraklık, tarımsal ve ekolojik sistemler üzerinde büyük bir etkiye sahiptir. Bitkiler, stresin yoğunluğu ve süresi kadar bitki çeşidine ve gelişim aşamasına bağlı olarak farklı şekillerde tepkiler gösterirler. Bitkilerin gösterdikleri bu tepkiler, stres faktörüne dayanımın ortaya çıkmasında büyük bir öneme sahiptir. Ancak genel olarak kuraklık stresi, üretimi sınırlandıran en önemli abiyotik streslerden biridir [26, 46]. Topraktaki su içeriğinin, bitkilerin gerekli suyu alamadıkları, belirgin yağışın olmadığı bir periyodu ifade eden kuraklık, toprağın su tutma kapasitesi ve bitkiler tarafından gerçekleştirilen evapotransprasyon hızı ile ilişkilidir [44].

Kuraklık stresi bitkilerde büyüme ve verim, bitkinin vegetatif ve generatif organları arasında su rekabeti, hücre içi yapılar, fotosentez ve azot metabolizması üzerine olumsuz etkilerde bulunarak bitki metabolizmasını bozmaktadır [30]. Ayrıca kuraklık sırasında büyüme için bir itici güç olan turgor basıncının azalması ve transpirasyonun olumsuz etkilenmesi nedeniyle mineral madde alımının gerilemesine de neden olabilmektedir [9].

Bitkilerin kuraklığa karş1 gösterdiği tepkiler, bitkinin içinde bulunduğu gelişme dönemine, kuraklığın süresine, şiddetine genetik faktörlere bağlı olarak değişebilmektedir [42-7-54]. Kuraklığa tolerans bakımından bitkiler arasında önemli farklılıklar bulunmakla birlikte, bu farklılıklar familya, cins ve türler arasında olabildiği gibi, aynı türe ait genotipler arasında da olabilmektedir [3, 1]. Kuraklığa dayanımı yüksek ve duyarlı genotiplerin metobolik aktiviteleri arasında farklıklar bulunabilmektedir. Bitkilerde kuraklığa dayanım üzerinde etkili olan fizyolojik ve morfolojik karakterler, bunlar arasındaki ilişkiler; genotipler düzeyinde farklılı̆̆ın ortaya konması ve tolerans mekanizmasının belirlenebilmesi bakımından önem taşımaktadır.

Patlican (Solanum melongena L.), domates (Solanum lycopersicum L.) ve kavun (Cucumis melo L.), ülkemizin kurak ve yarı kurak birçok bölgesinde açıkta ve örtü altında yoğun olarak yetiştiriciliği yapılan yazlık sebze türleridir. TÜIK verilerine göre Türkiye'de y1llık ortalama 827380 ton patlıcan, 11 850000 ton domates ve 1707302 ton kavun üretimi gerçekleştirilmektedir [4]. Yetiştiriciliğin yoğun olarak yapıldığı ve kuraklık sorununun potansiyel olarak mevcut olduğu bölgelerde, oluşan bu kuraklığa karşı bazı kültürel önlemler alınabilmekte ise de bu önlemler sınırlı ve maliyetlidir. Bu bakımdan kuraklığa dayanımı yüksek genotiplerin belirlenmesi ve ıslah programlarında kullanılması en etkili yöntemdir.

$\mathrm{Bu}$ araştırmada domates, patlıcan ve kavun türlerine ait genotiplerin, kuraklık stresi koşullarında ortaya çıkan morfolojik, fizyolojik ve biyokimyasal bazı özellikleri arasındaki korelatif ilişkiler incelenmiştir.

\section{Materyal ve Yöntem}

Çalışmada bitkisel materyal olarak daha önceki araştırmalarda [14-59-31] tuzluluk bakımından değerlendirilen gen havuzlarından seçilen 2'şer adet tolerant ve 2'şer adet duyarlı domates (Solanum lycopersicum L.), patlıcan (Solanum melongena L.) ve kavun (Cucumis melo L.) genotipi kullanılmıştır Çalışma, sıcaklık ve nem kontrolü otomatik olarak sağlanan cam serada yürütülmüştür $\left(23-25^{\circ} \mathrm{C}, \% 50-55\right.$ nispi nem). Genotiplere ait tohumlar, orta bünyeli toprak içeren $13 \mathrm{~L}$ hacme sahip plastik saksılara, her saksıda 10 bitki bulunacak șekilde ekilmişlerdir. Tüm deneme konularında yer alan bitkiler, 3-4 yapraklı 
oluncaya kadar tarla kapasitesi düzeyinde sulanmıştır. $\mathrm{Bu}$ aşamadan sonra bitkiler üç farklı düzeyde $\left(\mathrm{S}_{0}\right.$ : kontrol- yarayışlı suyun \% 40'1 tüketildiğinde sulama, $\mathrm{S}_{1}$ : yarayışlı suyun \% 90 '1 tüketildiğinde sulama, $\mathrm{S}_{2}: 3-4$ yaprak oluştuktan sonra susuz bırakma) sulanmıştır. Topraktaki nem miktarı, ağırlık esasına göre belirlenmiştir. Stres uygulamasının 12. gününde patlıcan ve domateste, 14. gününde kavun bitkilerinde kuraklık stresinin semptomatik etkileri belirgin olarak ortaya çıkmış, duyarlı veya dayanımı daha yüksek olan genotiplerde solma ve sararma gibi görsel kriterlerdeki ayırt edici farklılıklar net bir biçimde gözlemlenmiştir. Aynı gün deneme sonlandırılarak 0-5 skalası oluşturulmuş, bitki yaş ve kuru ağırlığı, yaprak alanı, nispi nem, stoma iletkenliği, yaprak su potansiyeli, iyon ve içerikleri, lipid peroksidasyonu düzeyi ve antioksidatif enzim aktiviteleri (SOD, GR, APX, CAT) bakımından değerlendirmeler yapılmıştır.

0-5 Skalası: Morfolojik olarak ortaya çıkan zararlanmanın derecesini ortaya koyabilmek amacıyla bir skala kullanılmıştır. Bunun için zararlanma derecesine göre bitkilere 0'dan 5'e kadar puan verilmiştir [34]. 0: Bitkilerin kuraklık stresinden hiç etkilenmemesi (kontrol bitkileri), 1: Büyümede yavaşlama, 2: Alt yapraklarda solgunluk başlangıcı, 3: Üst yapraklarda kıvrılma (kapanma) ve solgunluk, 4: Yapraklarda şiddetli solgunluk ve sararma, yaprak kenarlarında kuruma başlangıcı, 5: Bitkide solma ve alt yapraklarda kuruma.

Klorofil içeriğinin belirlenmesi: Klorofil analizleri için sürgün ucundan itibaren geriye doğru ilk üç yaprak alınmıştır. Örneklerden hazırlanan ve içinde klorofil bulunan çözeltinin absorbans değerleri spektrofotometrik olarak okunmuş, klorofil miktarı $\mu \mathrm{g} / \mathrm{mg}$ Taze Ağırlık olarak hesaplanmıştır [36].

Mineral element analizleri: Her bir yaprak örneğinden $250 \mathrm{mg}$ tartılıp alınarak, üzerine $15 \mathrm{ml}$ $0.1 \mathrm{~N} \mathrm{HNO}_{3}$ (Nitrik asit) ve bir damla toluen ilave edilen kapaklı plastik kutuların içinde karanlıkta bir hafta süreyle bekletilen örnekler, bu sürenin sonunda çalkalayıcıda 24 saat süreyle çalkalanmışlardır. Hazırlanan ekstraktlarda K, Ca, Mn, Zn ve Fe iyonları, spektrofotometrik atomik absorbsiyon yöntemiyle ölçülmüsşür. Bu ölçümler sonunda yaprak örneğindeki iyon miktarı, taze ağırlıktaki miktar (g/mg T.A) olarak belirlenmiştir [55].

Lipid peroksidasyonu: [37] tarafından anlatılan yöntem izlenerek gerçekleştirilen analizde; hücre zarlarının hasar görmesinin bir ifadesi olan lipid peroksidasyonunun ürünü 'malondialdehit (MDA)' miktarı, $\mu \mathrm{mol} / \mathrm{g}$ T.A. olarak belirlenmiştir.

Enzim analizleri: Enzim analizleri için $1 \mathrm{~g}$ taze yaprak ve doku örnekleri sıvı azot içerisinde porselen havanlarda ezildikten sonra, içinde $0.1 \mathrm{mM}$ Na-EDTA bulunan $50 \mathrm{mM}$ 'llk $10 \mathrm{ml}$ 'lik fosfor tampon çözeltisi (pH:7.6) ile homojenize edilmiş, $15 \mathrm{dk} 15000$ g'de santrifüj edildikten sonra ölçüm yapılıncaya kadar $+4^{\circ} \mathrm{C}$ sıcaklıkta tutulmuştur. Ölçümler Analytik Jena 40 model spektrofotometrede gerçekleştirilmiştir. Enzim ölçümünde son hacimler, tampon çözeltisiyle tamamlanmıştır. Süperoksit dismutaz (SOD) aktivitesi, NBT'nin (nitro blue tetrazolium kloridin) 1şık altında $\mathrm{O}^{2-}$ tarafından indirgenmesi yöntemine göre; katalaz aktivitesi (CAT), $\mathrm{H}_{2} \mathrm{O}_{2}$ 'nin $240 \mathrm{~nm}$ 'de $\left(\mathrm{E}=39.4 \mathrm{mM} \mathrm{cm}{ }^{-1}\right)$ parçalanma oranı esas alınarak ölçülmüştür [11-12]. Glutatyon reduktaz (GR) aktivitesi, [11] ve [12]'a göre $340 \mathrm{~nm}$ 'de $\left(E=6.2 \mathrm{mM} \mathrm{cm}^{-1}\right)$ NADPH'nın oksidasyonu esas alınarak, askorbat peroksidaz (APX) enzim aktivitesi [11] ve [12]'a göre, $290 \mathrm{~nm}$ 'de $\left(\mathrm{E}=2.8 \mathrm{mM} \mathrm{cm}^{-1}\right)$ askorbatın oksidasyonu ölçülerek belirlenmiştir. 
Tesadüf parsellerinde faktöriyel deneme desenine göre yürütülmüş denemelerden elde edilen verilerde MSTAT-C [17] bilgisayar paket programı kullanılarak korelasyon analizi [62] yapılmıştır.

\section{Bulgular}

Araştırmada tuz stresine toleransı yüksek veya düşük olmak üzere gruplandırılan dörder adet domates, patlıcan ve kavun genotipinde kuraklık stresi karşısında ortaya çıkan morfolojik ve fizyolojik bazı özellikler arasındaki ilişkiler ayrı ayrı sunulmuştur.

\subsection{Domates genotiplerinde incelenen parametreler arasında elde edilen korelasyon bulguları}

Ölçüm ve analizi yapılan fizyolojik ve biyokimyasal özellikler arasındaki ilişkilerin istatistiksel açıdan incelenmesinde korelasyon tablosundan yararlanılmıştır. Buna göre hazırlanan Tablo 1'de denemede incelenen tüm parametreler arasındaki ilişkiler, $\mathrm{P} \leq 0.01$ ve $\mathrm{P} \leq 0.05$ hata sınırı esas alınarak istatistiksel olarak önem dereceleri bakımından değerlendirilmiştir. Skala değerleri ile bitki yaş ve kuru ağırlığı, yaprak alanı, nispi nem miktarı, stoma iletkenliği, klorofil, Ca ve Fe miktarları arasında önemli düzeyde ancak negatif yönde bir ilişki görülürken (korelasyon katsayıları sırasıyla; 0.922**, 0.816*, $\left.0.963^{* *}, 0.881^{*}, 0.890^{* *}, 0.925^{* *}, 0.849^{*}, 0.926^{* *}\right)$ ayn özellik; yaprak su potansiyeli, MDA ve APX miktarları ile önemli düzeyde ve pozitif yönde bir korelasyon oluşturmuş̧ur $\left(0.927^{* *}, 0.925^{* *}, 0.825^{*}\right)$. Bitki yaş ağırlığı; bitki kuru ağırlığı, yaprak alanı, nispi nem içeriği, stoma iletkenliği, Ca miktarı ile önemli düzeyde korelasyon göstermiştir $\left(0.904^{* *}, 0.963^{* *}, 0.956^{* *}, 0.911^{* *}, 0.912^{* *}\right)$. Bitki yaş ağırlı̆̆ının klorofil $\left(0.889^{* *}\right)$ ve Fe miktarları $(0.842 *)$ ile olan istatistiksel ilişkisi nispeten daha düşük seviyelerde kalırken, yaprak su potansiyeli ile daha yüksek düzeyde ve negatif yönde bir korelasyon sergilemiştir $\left(0.968^{* *}\right)$. Bitki kuru ağırlığı incelenen parametreler arasında; stoma iletkenliği ile en yüksek $\left(0.978^{* *}\right)$, yaprak alanı $\left(0.883^{*}\right)$ ve nispi nem ile daha düşük seviyelerde korelasyon oluşturmuştur $\left(0.814^{*}\right)$. Aynı parametre, yaprak su potansiyeli ile önemli seviyede ve negatif yönde ilişki göstermiş̧tir $\left(0.968^{* *}\right)$. Yaprak alanı ile diğer parametreler arasındaki korelasyon ilişkileri incelendiğinde; en yüksek korelasyon katsayısını 'Yaprak alanı x Klorofil miktarı' kombinasyonu vermiş, bunu sırasılya; 'Yaprak alanı x Nispi nem içeriği' (0.933**), 'Yaprak alanı x Stoma iletkenliği'( 0.929), 'Yaprak alanı $x$ Ca miktarl' $\left(0,892^{* *}\right)$, 'Yaprak alan $x$ F miktarı' $\left(0,881^{*}\right)$ ve 'Yaprak alan $x$ K miktarı' $\left(0,808^{*}\right)$ kombinasyonları izlemiştir. 'Yaprak alanı x Yaprak su potansiyeli' ve 'Yaprak alanı x MDA miktarı' kombinasyonları istatistiksel bakımdan önemli düzeyde ve negatif yönde korelasyon göstermiş̧tir (0.954** ve $\left.0.957^{* *}\right)$. 'Nispi nem içeriği x Ca miktarı' kombinasyonu en yüksek düzeyde ve önemli seviyede korelasyon katsayısı vermiştir $\left(0.960^{* *}\right)$. Bu değeri 'Nispi nem içeriği x Klorofil miktarı' ve 'Nispi nem içeriği x Stoma iletkenliği' kombinasyonlarına ait değerler izlemiştir $\left(0.916^{* *}\right.$ ve $\left.0.825^{*}\right)$. Nispi nem içeriği; yaprak su potansiyeli ve MDA miktarı ile önemli seviyelerde ancak negatif yönde korelasyon oluşturmuştur. Stoma iletkenliği ile diğer bitkisel parametreler arasındaki korelasyon değerlendirmelerinde; klorofil ve $\mathrm{Fe}$ miktarları ile istatistiksel olarak önemli düzeyde bir ilişki belirlenmiştir $\left(0.871^{*}\right.$ ve $\left.0.826^{*}\right)$. Stoma iletkenliği; yaprak su potansiyeli ve MDA miktarı $\left(0.954^{* *}\right.$ ve $\left.0.805^{*}\right)$ ile, yaprak su potansiyeli; klorofil, Ca ve Fe miktarları $\left(0.883^{*}, 0.832^{*}\right.$ ve $\left.0.901^{* *}\right)$ ile, klorofil miktarı MDA miktarı $\left(0.989^{* *}\right)$ ile istatistiksel olarak önemli düzeyde ve negatif yönde korelasyon oluşturmuştur. 'Klorofil miktarı $x$ K miktarı' ve 'Klorofil miktarı $x$ Ca miktarı' kombinasyonları istatistiksel olarak önemli bulunmuştur $\left(0.887^{* *}\right.$ ve $\left.0.906^{* *}\right)$. 'K miktarl $x$ MDA miktarı' ve 'Ca miktarı $x$ 
Nevşehir Bilim ve Teknoloji Dergisi Cilt 4(2) 9-25 2015

Tablo 1. Araştırma konularına bağlı olarak domateste incelenen parametreler arasında elde edilen korelasyon katsayıları

\begin{tabular}{|c|c|c|c|c|c|c|c|c|c|c|c|c|c|c|c|c|c|c|c|}
\hline & & 1 & 2 & 3 & 4 & 5 & 6 & 7 & 8 & 9 & 10 & 11 & 12 & 13 & 14 & 15 & 16 & 17 & 18 \\
\hline 1 & Skala & 1,000 & & & & & & & & & & & & & & & & & \\
\hline 2 & Bit.Yaş Ağ. & $-0,922 * *$ & 1,000 & & & & & & & & & & & & & & & & \\
\hline 3 & Bit.Kuru A $\breve{g}$. & $-0,816^{*}$ & $0,904 * *$ & 1,000 & & & & & & & & & & & & & & & \\
\hline 4 & Yaprak Alanı & $-0,963 * *$ & 0,963 ** & $0,883 *$ & 1,000 & & & & & & & & & & & & & & \\
\hline 5 & Nispi Nem & $-0,881^{*}$ & $0,956^{* *}$ & $0,814 *$ & $0,933^{* *}$ & 1,000 & & & & & & & & & & & & & \\
\hline 6 & Stom İletk. & $-0,890 * *$ & $0,911^{* *}$ & $0,978 * *$ & $0,929 * *$ & $0,825^{*}$ & 1,000 & & & & & & & & & & & & \\
\hline 7 & Yap. Su Pot. & $0,927 * *$ & $-0,968 * *$ & $-0,924 * *$ & $-0,954 * *$ & $-0,930 * *$ & $-0,954 * *$ & 1,000 & & & & & & & & & & & \\
\hline 8 & Klorofil & $-0,925^{* *}$ & $0,889 * *$ & 0,763 & $0,960^{* *}$ & $0,916^{* *}$ & $0,826^{*}$ & $-0,883^{*}$ & 1,000 & & & & & & & & & & \\
\hline 9 & $\mathrm{~K}$ & $-0,735$ & 0,744 & 0,542 & $0,808^{*}$ & $0,856^{*}$ & 0,575 & $-0,680$ & $0,887 * *$ & 1,000 & & & & & & & & & \\
\hline 10 & $\mathrm{Ca}$ & $-0,849^{*}$ & $0,912^{* *}$ & 0,724 & $0,892^{* *}$ & $0,960^{* *}$ & 0,728 & $-0,832 *$ & $0,906^{* *}$ & $0,885^{*}$ & 1,000 & & & & & & & & \\
\hline 11 & $\mathrm{Zn}$ & $-0,781$ & $0,798^{*}$ & 0,599 & 0,749 & 0,770 & 0,661 & $-0,780$ & 0,724 & 0,490 & 0,761 & 1,000 & & & & & & & \\
\hline 12 & Mn & $-0,656$ & 0,475 & 0,568 & 0,633 & 0,360 & 0,682 & $-0,572$ & 0,572 & 0,361 & 0,249 & 0,221 & 1,000 & & & & & & \\
\hline 13 & $\mathrm{Fe}$ & $-0,926^{* *}$ & $0,842^{*}$ & 0,770 & $0,881^{*}$ & 0,761 & $0,871^{*}$ & $-0,901 * *$ & $0,828^{*}$ & 0,520 & 0,677 & $0,843^{*}$ & 0,693 & 1,000 & & & & & \\
\hline 14 & MDA & $0,925 * *$ & $-0,346$ & $-0,730$ & $-0,957 * *$ & $-0,924 * *$ & $-0,805^{*}$ & $0,883^{*}$ & $-0,989 * *$ & $-0,900 * *$ & $-0,900 * *$ & $-0,735$ & $-0,582$ & $-0,836^{*}$ & 1,000 & & & & \\
\hline 15 & SOD & 0,399 & $-0,346$ & $-0,462$ & $-0,282$ & $-0,171$ & $-0,504$ & 0,458 & $-0,110$ & 0,273 & $-0,001$ & $-0,398$ & $-0,464$ & $-0,602$ & 0,119 & 1,000 & & & \\
\hline 16 & CAT & 0,123 & $-0,249$ & $-0,475$ & $-0,113$ & $-0,171$ & $-0,409$ & 0,377 & 0,037 & 0,300 & 0,007 & $-0,202$ & $-0,028$ & $-0,264$ & $-0,056$ & 0,711 & 1,000 & & \\
\hline 17 & GR & 0,538 & $-0,568$ & $-0,690$ & $-0,501$ & $-0,477$ & $-0,698$ & 0,704 & $-0,354$ & $-0,098$ & $-0,270$ & $-0,384$ & $-0,505$ & $-0,630$ & 0,374 & $0,813^{*}$ & $0,808^{*}$ & 1,000 & \\
\hline 18 & APX & $0,825^{*}$ & $-0,648$ & $-0,538$ & $-0,682$ & $-0,603$ & $-0,620$ & 0,674 & $-0,658$ & $-0,520$ & $-0,582$ & $-0,487$ & $-0,615$ & $-0,715$ & 0,672 & 0,488 & 0,131 & 0,576 & 1,000 \\
\hline
\end{tabular}


MDA miktarl' kombinasyonları istatistiksel olarak aynı ve önemli seviyede bir korelasyon vermiş, ancak bu ilişkinin yönü negatif olmuştur $\left(0.900^{* *}\right)$. Korelasyon incelemelerinde; 'Zn miktarı x Fe miktarı', 'Fe miktarl x MDA miktarı', 'SOD miktarl x GR miktarı' ve 'CAT miktarl x GR miktarı' kombinasyonları arasında da istatistiksel bakımdan önemli düzeyde ilişki tespit edilmiştir. Elde edilen korelasyon katsayıları sırasıyla; $0.843 *, 0.836 *, 0.813 *$ ve $0.808 *$ olarak belirlenmiştir.

\subsection{Patlican genotiplerinde incelenen parametreler arasında elde edilen korelasyon bulguları}

Kuraklık stresi sonrasında elde edilen sonuçlar 1şı̆̆ında incelenen parametreler arasındaki ilişkilerin istatistiksel açıdan incelenmesinden elde edilen korelasyon katsayıları Tablo 2' de gösterilmiştir. Buna göre, görsel zararlanma derecesine göre oluşturulan skala değerleriyle, bitki yaş ve kuru ağırlığı, yaprak alanı, nispi nem içeriği, stoma iletkenliği, $\mathrm{K}$ ve Ca içerikleri arasında negatif yönde ve istatistiksel bakımdan önemli düzeyde ilişki bulunduğu görülmektedir (korelasyon katsayıları sırasıyla; $\left.0.833^{*}, 0.843^{*}, 0.882^{*}, 0.859^{*}, 0.892^{*}, 0.830^{*}\right)$. Skala değerleriyle ile yaprak su potansiyeli ve MDA miktarı arasında önemli düzeyde korelasyon belirlenmiş olup, en yüksek korelasyon katsayıları 'Skala $x$ Yaprak su potansiyeli‘ ve 'Skala x MDA miktarı' kombinasyonlarında tespit edilmiştir (korelasyon katsayıları sırasıyla; $0.940 * *, 0.934^{* *}$ ). Araştırma konularına bağlı olarak bitki yaş ağırlığı; bitki kuru ağırlı̆̆ı, stoma iletkenliği ve $\mathrm{K}$ içeriği ile önemli düzeyde korelasyon oluşturmuştur (korelasyon katsayıları; $0.895^{* *}, 0.881^{*}$ ve $\left.0.900^{* *}\right)$. Aynı özellik MDA içeriği ile negatif yönde ve önemli düzeyde bir ilişki ortaya koymuştur $\left(0.835^{*}\right)$. Bitki kuru ağırlığı; yaprak alanı, stoma iletkenliği, nispi nem, $\mathrm{K}$ miktarı ile önemli seviyelerde istatistiksel ilişki göstermiş olup, en yüksek korelasyon katsayısı 'Bitki kuru ă̆ırllğı $x$ Stoma iletkenliği', 'Bitki kuru ă̆ırlı̆̆g $x$ Yaprak alanı', 'Bitki kuru ă̆ırll̆ğ $x$ Nispi nem içeriği' kombinasyonlarına ait değerler izlenmiştir $\left(0.956^{* *}, 0.861^{*}, 0.837^{*}\right)$. Bitki kuru ağırlığının MDA miktarı ile olan korelasyonu önemli seviyede fakat negatif yönde gerçekleşmiştir $\left(0.935^{* *}\right)$. Kuraklık stresi sonrasında ölçülen yaprak alanı değerleri ile $\mathrm{K}$ miktarı arasındaki ilişki istatistiksel açıdan incelendiğinde; bu ilişkinin önemli düzeyde olduğu görülmüştür $\left(0.897^{* *}\right)$. 'Yaprak alanı x Yaprak su potansiyeli' ve 'Yaprak alanı x MDA miktarı' kombinasyonları arasındaki korelasyon katsayıları negatif yönde ve önemli düzeyde olup $0.866^{*}$ ve $0.939^{* *}$ şeklinde belirlenmiştir. Nispi nem içeriğinin; stoma iletkenliği ile olan istatistiksel ilişkisi önemli düzeyde (0.864*) olup, benzer ilişki 'Nispi nem x Yaprak su potansiyeli' ve 'Nispi nem x SOD miktarı' kombinasyonları arasında da negatif yönde tespit edilmiştir $\left(0.823 *\right.$ ve $\left.0.825^{*}\right)$. Stoma iletkenliğinin yaprak su potansiyeli ve MDA miktarı ile olan istatistiksel ilişkisi önemli düzeyde ve negatif yönde bulunurken $\left(0.855^{*}\right.$ ve $\left.0.879 *\right)$, benzer ilişki 'Stoma iletkenliğix $K$ miktarl' kombinasyonunda da ortaya çıkmış ve en yüksek korelasyon katsayısını oluşturmuştur $\left(0.923^{* *}\right)$. Yaprak su potansiyelinin; klorofil, K, Ca, Zn, Mn miktarları ile olan istatistiksel ilişkileri incelendiğinde, önemli seviyede ve negatif yönde olduğu görülmüştür (korelasyon katsayıları sırasıyla; $\left.0.812^{*}, 0.915^{* *}, 0.915^{* *}, 0.929^{* *}, 0.833^{*}\right)$. Yaprak su potansiyeli, incelenen parametreler arasinda sadece MDA miktarı ile en yüksek ve önemli düzeyde korelasyon göstermiştir ( $\left.0.956^{* *}\right)$. Klorofil miktarı ile incelenen bitki parametreleri arasındaki istatistiksel ilişkide; en yüksek korelasyon katsayıları 'Klorofil miktarl x Ca miktarl', 'Klorofil miktarl $x$ Mn miktarl' ve 'Klorofil miktarl $x$ Fe miktarı' kombinasyonlarında belirlenmiş ve ortaya çıkan istatistiksel ilişki önemli bulunmuştur $\left(0.850^{*}, 0.864^{*}\right.$, $\left.0.869^{*}\right)$. Bitkiler için önemli bir element olan Ca miktarı; Zn, Mn, Fe miktarlarıla önemli seviyede 
Tablo 2. Patlıcanda incelenen parametreler arasında elde edilen korelasyon katsayıları

\begin{tabular}{|c|c|c|c|c|c|c|c|c|c|c|c|c|c|c|c|c|c|c|c|}
\hline & & 1 & 2 & 3 & 4 & 5 & 6 & 7 & 8 & 9 & 10 & 11 & 12 & 13 & 14 & 15 & 16 & 17 & 18 \\
\hline 1 & Skala & 1.000 & & & & & & & & & & & & & & & & & \\
\hline 2 & Bit.Yaş Ă̆. & $-0.833^{*}$ & 1.000 & & & & & & & & & & & & & & & & \\
\hline 3 & Bit.Kuru A $\breve{g}$. & $-0.906^{* *}$ & $0.895 * *$ & 1.000 & & & & & & & & & & & & & & & \\
\hline 4 & Yaprak Alanı & $-0.843 *$ & 0.790 & $0.861^{*}$ & 1.000 & & & & & & & & & & & & & & \\
\hline 5 & Nispi Nem & $-0.882^{*}$ & 0.777 & $0.837^{*}$ & 0.602 & 1.000 & & & & & & & & & & & & & \\
\hline 6 & Stom İlet. & $-0.859^{*}$ & $0.881 *$ & $0.971^{* *}$ & 0.746 & $0.864 *$ & 1.000 & & & & & & & & & & & & \\
\hline 7 & Yap. Su Pot. & $0.940 * *$ & -0.761 & $-0.893 * *$ & $-0.866^{*}$ & $-0.823^{*}$ & $-0.855^{*}$ & 1.000 & & & & & & & & & & & \\
\hline 8 & Klorofil & -0.749 & 0.672 & 0.675 & 0.687 & 0.775 & 0.637 & $-0.812 *$ & 1.000 & & & & & & & & & & \\
\hline 9 & K & $-0.892 * *$ & $0.900 * *$ & $0.956^{* *}$ & 0.897 ** & 0.782 & $0.923 * *$ & $-0.915^{* *}$ & 0.780 & 1.000 & & & & & & & & & \\
\hline 10 & $\mathrm{Ca}$ & $-0.830 *$ & 0.629 & $0.839^{*}$ & 0.792 & 0.777 & 0.790 & $-0.915^{* *}$ & $0.850^{*}$ & $0.871^{*}$ & 1.000 & & & & & & & & \\
\hline 11 & $\mathrm{Zn}$ & -0.796 & 0.610 & $0.810^{*}$ & $0.847^{*}$ & 0.673 & 0.761 & $-0.929 * *$ & 0.804 & $0.879 *$ & $0.959 * *$ & 1.000 & & & & & & & \\
\hline 12 & $\mathrm{Mn}$ & -0.731 & 0.669 & $0.814^{*}$ & $0.832 *$ & 0.701 & 0.738 & $-0.833^{*}$ & $0.864 *$ & $0.855^{*}$ & $0.928 * *$ & $0.908 * *$ & 1.000 & & & & & & \\
\hline 13 & $\mathrm{Fe}$ & -0.592 & 0.562 & 0.700 & 0.669 & 0.645 & 0.674 & -0.742 & $0.869^{*}$ & 0.781 & $0.897 * *$ & $0.873^{*}$ & $0.945^{* *}$ & 1.000 & & & & & \\
\hline 14 & MDA & $0.934 * *$ & $-0.835^{*}$ & $-0.935 * *$ & $-0.939 * *$ & -0.761 & $-0.879^{*}$ & $0.956^{* * *}$ & -0.690 & $-0.934 * *$ & $-0.824 *$ & $-0.869^{*}$ & -0.793 & -0.645 & 1.000 & & & & \\
\hline 15 & SOD & 0.704 & -0.487 & -0.487 & -0.349 & $-0.825^{*}$ & -0.487 & 0.550 & -0.718 & -0.484 & -0.501 & -0.353 & -0.428 & -0.376 & 0.448 & 1.000 & & & \\
\hline 16 & CAT & 0.456 & -0.722 & -0.391 & -0.524 & -0.370 & -0.363 & 0.397 & -0.507 & -0.492 & -0.161 & -0.231 & -0.318 & -0.220 & 0.483 & 0.465 & 1.000 & & \\
\hline 17 & GR & 0.235 & -0.566 & -0.245 & -0.417 & -0.130 & -0.233 & 0.242 & -0.279 & -0.339 & 0.027 & -0.111 & -0.174 & -0.085 & 0.370 & 0.139 & $0.929 * *$ & 1.000 & \\
\hline 18 & APX & 0.256 & -0.524 & -0.273 & -0.346 & -0.394 & -0.270 & 0.308 & -0.686 & -0.386 & -0.275 & -0.281 & -0.504 & -0.533 & 0.279 & 0.469 & 0.775 & 0.697 & 1.000 \\
\hline
\end{tabular}


korelasyonlar oluşturmuş $\left(0.959^{* *}, 0.928^{* *}, 0.897^{* *}\right)$ ve en yüksek korelasyon katsayısı 'Ca miktarı $x$ Zn miktarl' kombinasyonunda tespit edilmiştir. 'Ca miktarl x MDA miktarı' kombinasyonu istatistiksel olarak önemli seviyede ve negatif yönde önemli bulunmuştur $(0.824 *)$. Zn miktarının diğer parametrelerle olan ilişkisi incelendiğinde; $\mathrm{Mn}$ ve Fe miktarları ile istatistiksel olarak önemli düzeyde korelasyon oluşturduğu belirlenmiş $\left(0.908^{* *}, 0.873^{*}\right)$, MDA miktarları arasındaki ilişki de önemli bulunmuş ancak bu ilişki negatif yönde gerçekleşmiştir $\left(0.869^{*}\right)$. Mn ile Fe miktarları ve CAT ile GR miktarları arasında da dikkate değer ilişkiler görülmüştür $\left(0.945^{* *}\right.$ ve $\left.0.929^{* *}\right)$.

\subsection{Kavun genotiplerinde incelenen parametreler arasında elde edilen korelasyon bulguları}

Kavun genotiplerinde elde edilen bulgulara göre incelenen parametreler arasındaki ilişkilerin verildiği korelasyon tablosu incelendiğinde; bitkilerin görsel zararlanma derecesinin bir ifadesi olan skalanın bitki yaş ve kuru ağırlığı, yaprak alanı, nispi nem içeriğii, stoma iletkenliği, klorofil, $\mathrm{Ca}$, Zn ve Fe miktarları ile olan istatistiksel ilişkileri negatif yönde ve önemli bulunmuştur (korelasyon katsayıları sirasiyla; 0.914**, 0.864* $\left.0.988^{* *}, 0.869^{*}, 0.829^{*}, 0.938^{* *}, 0.987^{* *}, 0.880^{*}, 0.862^{*}\right)$. Aynı parametre yaprak su potansiyeli ve MDA miktarları ile de önemli bir korelasyon oluşturmuştur $\left(0.977^{* *}\right.$ ve 0.894**) (Tablo 3). Bitki yaş ağırlı̆̆ı; yaprak alanı, Ca ve Zn miktarları ile istatistiksel olarak önemli seviyede korelasyon göstermiştir. En yüksek korelasyon katsayısı 'Bitki yaş ağırlı̆̆ $x$ Ca miktarl' kombinasyonunda (0.925**) belirlenirken, 'Bitki yaş ağıllığl $x$ Yaprak alanı' ve 'Bitki yaş ağırlı̆̆l $x$ Zn miktarl' kombinasyonlarına ait korelasyon katsayıları birbirlerine yakın olmuştur $(0.878 *$ ve $0.877 *)$. Aynı özellik, yaprak su potansiyeli ile önemli seviyede ve negatif yönde korelasyona yol açmıştır $\left(0.898^{* *}\right)$. Yaprak alanı; nispi nem, klorofil, $\mathrm{Ca}, \mathrm{Zn}$ ve Fe içerikleri ile istatistiksel olarak önemli düzeyde ilişki sergilemiştir. En yüksek korelasyon katsayıları 'Yaprak alanı x Klorofil miktarı' ve 'Yaprak alanı x Ca miktarı' kombinasyonlarında belirlenmiştir (0.966** ve 0.934**). Yaprak alanı x Zn miktarı' ile 'Yaprak alanı x Nispi nem içeriği' kombinasyonları benzer korelasyon katsayısını ortaya koymuş olup $\left(0.889^{* *}\right)$, bu değeri 'Yaprak alanı x Fe miktarı' kombinasyonuna ait katsayı izlemiş̧tir $(0.872 *)$. Yaprak alanı; yaprak su potansiyeli ve MDA miktarı ile de önemli derecede negatif bir korelasyon oluşturmuştur $(0.960 * *$ ve $0.852 *)$. Stres sonucunda oluşan nispi nem içeriğinin; klorofil, Ca ve $\mathrm{Zn}$ miktarları ile olan ilişkisi istatistiksel olarak önemli bulunmuştur. 'Ca miktarı x Nispi nem içeriği ' kombinasyonu oldukça yüksek bir korelasyon katsayısı göstermiştir $\left(0.984^{* *}\right)$. Bunu sırasıyla 'Nispi nem içeriği $x$ Zn miktarı' ve 'Nispi nem içeriği x klorofil miktarı' kombinasyonlarına ait korelasyon katsayıları takip etmiştir $(0.872 *$ ve $0.844 *)$. Bitki yapraklarında ölçülen stoma iletkenliği; stres sonrasında yapraklarda tespit edilmiş olan Ca, klorofil ve Fe miktarları ile önemli düzeyde ve aynı yönde $\left(0.942^{* *}\right.$, $0.900^{* *}, 0.832 *$, yaprak su potansiyeli ile önemli düzeyde fakat zıt yönde bir korelasyon oluşturmuştur (0.824*). 'Yaprak su potansiyeli x MDA miktarı' kombinasyonu doğrusal yönde ve önemli düzeyde bir korelasyon vermiştir $\left(0.841^{*}\right)$. Aynı özellik yapraklarda ölçülen klorofil, $\mathrm{Ca}, \mathrm{Zn}$ ve Fe miktarları ile negatif yönlü bir korelasyon meydana getirmiştir $\left(0.931^{* *}, 0.986^{* *}, 0.822^{*}, 0.903^{* *}\right)$. Klorofil ve $\mathrm{K}$ miktarları; Ca miktarı ile istatistiksel olarak önemli seviyelerde bir ilişki sergilemiştir. En yüksek korelasyon katsayısı 'Klorofil x Ca miktarı' kombinasyonunda ortaya çıkmış, bunu 'K miktarı x Ca miktarı’ kombinasyonu izlemiş̧ir $\left(0.991^{* *}, 0.910^{* *}\right)$. Klorofil ve MDA miktarları arasındaki ilişki de önemli düzeyde ve negatif yönde bulunmuştur( $\left(0.811^{*}\right)$. Önemli bir element olan Ca içeriği; $\mathrm{Zn}, \mathrm{Mn}$ ve Fe 
Tablo 3. Kavunda incelenen parametreler arasında elde edilen korelasyon katsayıları

\begin{tabular}{|c|c|c|c|c|c|c|c|c|c|c|c|c|c|c|c|c|c|c|c|}
\hline & & 1 & 2 & 3 & 4 & 5 & 6 & 7 & 8 & 9 & 10 & 11 & 12 & 13 & 14 & 15 & 16 & 17 & 18 \\
\hline 1 & Skala & 1.000 & & & & & & & & & & & & & & & & & \\
\hline 2 & Bit.Yaş A $\breve{g}$. & $-0.914 * *$ & 1.000 & & & & & & & & & & & & & & & & \\
\hline 3 & Bit.Kuru A $\breve{g}$. & $-0.864 *$ & 0.777 & 1.000 & & & & & & & & & & & & & & & \\
\hline 4 & Yaprak Alanı & $-0.988 * *$ & $0.907 * *$ & $0.878^{*}$ & 1.000 & & & & & & & & & & & & & & \\
\hline 5 & Nispi Nem & $-0.869^{*}$ & 0.774 & 0.708 & $0.889^{* *}$ & 1.000 & & & & & & & & & & & & & \\
\hline 6 & Stom İletk. & $-0.829 *$ & $0.869^{*}$ & 0.569 & $0.830^{*}$ & 0.734 & 1.000 & & & & & & & & & & & & \\
\hline 7 & Yap. Su Pot. & $0.977^{* * *}$ & $-0.937 * *$ & $-0.898^{* *}$ & $-0.960^{* *}$ & -0.789 & $-0.824 *$ & 1.000 & & & & & & & & & & & \\
\hline 8 & Klorofil & $-0.938^{* *}$ & $0.972 * *$ & 0.745 & $0.934 * *$ & $0.844^{*}$ & $0.900^{* *}$ & $-0.931 * *$ & 1.000 & & & & & & & & & & \\
\hline 9 & K & -0.703 & 0.608 & 0.717 & 0.688 & 0.297 & 0.542 & -0.752 & 0.592 & 1.000 & & & & & & & & & \\
\hline 10 & $\mathrm{Ca}$ & $-0.987 * *$ & $0.986^{* *}$ & $0.925^{* *}$ & $0.966^{* *}$ & $0.984 * *$ & $0.942 * *$ & $-0.986^{* *}$ & $0.991^{* *}$ & $0.910^{* *}$ & 1.000 & & & & & & & & \\
\hline 11 & $\mathrm{Zn}$ & $-0.880^{*}$ & 0.673 & $0.877^{*}$ & $0.889^{* *}$ & $0.872^{*}$ & 0.538 & $-0.822 *$ & 0.714 & 0.537 & $0.932^{* *}$ & 1.000 & & & & & & & \\
\hline 12 & $\mathrm{Mn}$ & -0.511 & 0.734 & 0.513 & 0.557 & 0.407 & 0.722 & -0.603 & 0.704 & 0.422 & $0.896^{* *}$ & 0.221 & 1.000 & & & & & & \\
\hline 13 & $\mathrm{Fe}$ & $-0.862^{*}$ & $0.882 *$ & $0.840^{*}$ & $0.872^{*}$ & 0.788 & $0.832 *$ & $-0.903^{* *}$ & $0.864 *$ & 0.543 & $0.795^{*}$ & 0.744 & 0.729 & 1.000 & & & & & \\
\hline 14 & MDA & $0.894 * *$ & -0.734 & -0.715 & $-0.852^{*}$ & -0.767 & -0.647 & $0.841^{*}$ & $-0.811^{*}$ & -0.648 & $-0.935^{* *}$ & $-0.804 *$ & -0.266 & -0.596 & 1.000 & & & & \\
\hline 15 & SOD & 0.152 & -0.450 & 0.069 & -0.146 & -0.258 & -0.546 & 0.194 & -0.424 & 0.232 & -0.667 & 0.152 & -0.624 & -0.422 & -0.065 & 1.000 & & & \\
\hline 16 & CAT & 0.465 & -0.681 & -0.357 & -0.458 & -0.396 & -0.738 & 0.554 & -0.612 & -0.208 & -0.352 & -0.180 & -0.756 & -0.765 & $0.828^{*}$ & $0.828 *$ & 1.000 & & \\
\hline 17 & GR & 0.429 & -0.672 & -0.188 & -0.365 & -0.298 & -0.684 & 0.505 & -0.606 & -0.179 & $-0.894 * *$ & -0.044 & -0.594 & -0.563 & 0.252 & $0.835^{*}$ & $0.869^{*}$ & 1.000 & \\
\hline 18 & APX & 0.094 & -0.423 & 0.067 & -0.078 & -0.119 & -0.478 & 0.181 & -0.363 & 0.167 & -0.380 & 0.231 & -0.638 & -0.404 & -0.147 & $0.969 * *$ & $0.863^{*}$ & $0.867^{*}$ & 1.000 \\
\hline
\end{tabular}


içerikleri ile istatistiksel olarak önemli düzeyde bir bağlantı sergilemiştir (sırasıyla; 0.932**, 0.896**, 0.795*). Ca içeriği ile MDA ve GR miktarları arasında da önemli seviyelerde fakat negatif yönde bir ilişki tespit edilmiştir $\left(0.935^{* *}\right.$ ve $\left.0.894^{* *}\right)$. Aynı ilişki Zn ile MDA miktarları arasında da tespit edilmiştir (0.804*). MDA içeriği; CAT içeriği ile $\left(0.828^{*}\right)$, SOD içeriği; CAT, GR ve APX içerikleri ile $\left(0.828^{*}, 0.835^{*}, 0.969^{* *}\right)$; GR içeriği ise; sadece APX içeriği $\left(0.867^{*}\right)$ ile istatistiksel olarak önemli düzeyde korelasyon göstermiştir.

\section{Tartışma ve Sonuç}

Daha önceki çalışmalarda tuza dayanım durumları belirlenerek, dayanımı yüksek veya düşük olmak üzere gruplandırılan dörder adet patlıcan, domates ve kavun genotipinin, kök bölgesinde oluşturulan kuraklık stresine karşı göstermiş oldukları tepkileri belirlenmiştir. Kurak koşullarda yetiştirilen domateste ve patlıcanda 12. günde, kavunda ise 14. günde ortaya çıan zararlanma belirtilerine göre oluşturulan skala değerlendirmeleri; tüm genotiplerin kuraklıktan morfolojik olarak hasar görme derecelerini göstermiştir. Fide dönemindeki bitkiler kullanılarak saksı denemeleri yöntemiyle yapılan bu araştırmada da patlıcan, domates ve kavuna ait farklı genotiplerde kuraklık stresinden kaynaklanan semptomlar, farklı seviyelerde ortaya çıkmıştır. Kuraklığa daha iyi tolerans göstererek daha düşük skala değerleri alan genotiplerin ağırlık kayıpları ve yaprak alanındaki azalmalar daha az olmuş, kuraklı̆ga duyarlı genotiplerin skala değerleri daha yüksek bulunduğu gibi ağırlık kayıpları ve alanları gibi diğer morfolojik zarar görme kriterleri de yüksek değerler vermiştir. Bu nedenle morfolojik özellikler arasında çok yüksek düzeyde bir korelasyon bulunmuştur. Skala değerleri ile bitki yaş ağırlığı, bitki kuru ağırlığı, yaprak alanı gibi büyüme parametreleri arasında negatif yönde kuvvetli bir korelasyon belirlenmiş olup skala değeri yani zararlanma arttıkça, büyüme parametrelerinde de değişen oranlarda azalma meydana gelmiştir. Nitekim bamya genotipleri arasında kuraklığa tolerant olanların belirlenmesi amacıyla yapılan çalışmada da görsel skala (0-5 skalası) değerleri önemli gruplandırmalar sağlamış, yeşil aksam yaş ve kuru ağırlığı, bitki boyu, gövde çapı ve yaprak sayısı gibi büyüme parametreleri kuraklıktan olumsuz etkilenmiş̧ir. Bu nedenle araştırıcılar, yaş ve kuru ağırlık kayıplarının ön seçim aşamasında önemli bir tarama faktörü olabileceğini ileri sürmüşlerdir [32]. Yaprakların kuraklık koşullardan en fazla etkilenen organlar olduğunu ve turgor kaybının ilk belirtilerden sayıldığını bildiren araştırmalar olduğu gibi [1]; birçok çalışmada bitki büyümesi ve gelişmesinin de stres koşullarından olumsuz yönde etkilendiği ortaya konulmuştur [47]. Fasulyede [10] ve mısırda [24-21], kuraklı̆̆ın yaş ve kuru ağırlık gibi bazı büyüme parametrelerini olumsuz yönde etkilediği ve kuraklığa adapte olmuş genotiplerde kayıpların daha az olduğu bildirilmektedir.

Kuraklık koşullarında her üç türde de nispi nem içeriği, stoma iletkenliği ve yaprak su potansiyellerinde önemli düşüşler belirlenmiş̧ir. Strese bağlı olarak bitki yaş ve kuru ağırlığı ile yaprak alanı ve nispi nem oranında azalma meydana gelmiş ve negatif bir korelasyon oluşturmuştur. Bunun yanı sıra bitkilerdeki zararlanma dolayısıyla skala değeri artıkça stoma iletkenliğinde de azalma meydana gelmiştir. Yaprak alanındaki ve stoma iletkenliğindeki azalmanın bir sonucu olarak klorofil miktarı da negatif yönde etkilenmiştir. Stomaların kapanması bitkilerin suyu dokularında tutmalarını sağlayan kuraklıktan kaçınma mekanizmalarından biri olmakla beraber, $\mathrm{CO}_{2}$ 'in mezofil hücrelerine girmelerini önlediğinden fotosentetik hızı azaltabilmekte ve sonuçta büyüme hızı da yavaşlayabilmektedir [10]. Buğdayda [38], kavunda [33] stoma yoğunluklarının çeşidin kuraklığa dayanım performansını etkileyen önemli faktörler olduğu; kuraklığın, stomatal regülasyonu olumsuz yönde etkilediği, kuraklığa adapte olmuş bitkilerde transpirasyon oranının düşük, stomatal regülasyonun yüksek olduğu bildirilmiştir. Kuraklığın mercimek bitkisinin stoma iletkenliğine ait değerlerinde önemli düzeyde 
artışlara neden olduğu, stoma iletkenliği yüksek olan çeşitlerin kurağa tolerant olduğu literatürde yer almaktadır [19]. Kuraklık koşullarında bitkilerin, nispi nem içeriği ve yaprak su potansiyelindeki azalmaya bağlı olarak turgoritesini kaybetmesi, stomaların kapanmasına neden olabilmektedir [7]. Kuraklığa bağlı olarak değişen su durumunu belirleyebilmek için yapılan yaprak su potansiyeli ölçümlerine göre, stres uygulamasından itibaren üç türe ait genotiplerin yaprak su potansiyelinde azalma görülmüştür. Nitekim domates genotiplerinde yaprak su potansiyelinin kuraklık stresinin etkisini belirlemede önemli bir parametre olarak değerlendirilebileceği [53], bamyada kuraklık ile birlikte yüksek sıcaklığın yaprak su potansiyelini olumsuz yönde etkileyeceği ifade edilmektedir [6]. Buğday ve bezelyede [2], kavunda [35] ve börülcede [8] yapılan çalışmalarda da, kuraklık stresinin yaprak su potansiyelinde azalmaya yol açtığı bildirilmektedir.

Kuraklığa bağlı olarak değişen su durumunu belirleyebilmek için yapılan nispi nem içeriği ölçümlerine göre, kuraklık stresi su içeriğinde azalmaya neden olmuştur. Bu durum, genotiplerin toprak kuruması sırasında uygun su seviyelerini koruyamadıklarını göstermektedir. Bitkilerin su kaybından dolayı turgor kaybına uğramasının bir göstergesi olabilir. Hint kamışı bitkisinde, kuraklık ile birlikte nispi nem değerinde \% 35 düzeyinde azalma meydana gelebileceği ifade edilmekte olup [48], fasulye çeşitlerinde [45] ve domates genotiplerinde [53] de farklı seviyelerdeki kuraklığın nispi nem değerinde azalmaya neden olduğu ifade edilmektedir. Patlıcanda farklı düzeylerde kuraklık stresi uygulanan bir çalışmada en az düzeyde strese tabi tutulan bitkilerdeki nispi nem içeriğinin, stres şiddeti yüksek olan bitkilerden daha fazla olduğu belirlenmiştir [29]. Fasulye türlerinin kuraklığa karşı verdikleri yanıtların karşılaştırıldığı bir araştırmada, yabani tür fasulyenin kuraklığa daha tolerant olduğu ve stres koşullarında yabani türde nispi nem içeriğinin, kültür formuna göre daha yüksek olduğu saptanmıştır [57].

Klorofil, bitkilerde abiyotik stres koşullarında hemen etkilenen faktörlerdin birisidir. Klorofil kaybını en az düzeyde tutabilen genotiplerin stres koşullarına daha iyi dayandığı belirgin bir şekilde görülmektedir. Klorofil, domates ve kavunda kuraklık stresine bağlı olarak skala değeriyle önemli ve olumsuz yönde bir ilişki sergilemiş, stresin etkisi arttıkça bitkilerin klorofil miktarında azalma meydana gelmiştir. Ayrıca klorofil, içeriğindeki azalmayla birlikte bitkilerin bitki yaş ağırlığı ile yaprak alanı ve nispi nem oranında azalma meydana gelmiş ve olumlu yönde bir korelasyon oluşturmuştur. Kontrol bitkilerine göre klorofil kaybı, tüm genotiplerde net ve açık olmakla birlikte çeşit ayrımı bakımından etkinliği düşük bir kriter olarak kendini göstermiştir. Bununla birlikte klorofil kaybı, kuraklık çalışmalarında incelenen bir parametre olarak kullanılmakla birlikte [42-43], klorofilin tarama çalışmalarında ayırt edici bir faktör olma konusunda zayıf kaldı ̆̆ı belirtilmiştir [58-51].

Kuraklık stresinin en önemli etkilerinden biri de bitki besin elementlerindeki azalma olmuştur. Zararlanma düzeyine bağlı olarak bitki bünyesindeki $\mathrm{Ca}, \mathrm{K}, \mathrm{Zn}, \mathrm{Fe}$ ve $\mathrm{Mn}$ elementlerinde de azalma belirlenmiştir. Kuraklık stresinin patlıcanda, domateste ve kavunda iyon içeriklerine olan etkisi, azalma yönünde olmuştur. K, Ca, Mn, Zn ve Fe içerikleri bakımından her üç türde de kuraklık stresi bitkiler üzerinde olumsuz etki yapmıştır. Nitekim oksidatif stres ile birlikte $\mathrm{K}, \mathrm{Ca}, \mathrm{Fe}$ ve $\mathrm{Mn}$ konsantrasyonlarında azalma meydana geldiği belirtilmektedir [52]. Bitkilerde $\mathrm{K}$ iyonunun aktif alımıyla hücrelerdeki ozmotik potansiyel yükseltilmekte ve böylece bitkiye su girişi mümkün olabilmektedir. Potasyum, bitkide su alımının gerçekleşebilmesi için büyük öneme sahiptir [58]. Karpuzda kuraklık stresi uygulandığında bitki bünyesinde potasyum konsantrasyonunda azalma meydana geldiğini belirlenmiş; bu elementin, stomaların açılıp kapanması, fotosentetik etki ve su dengesinin korunmasında etkili olduğu vurgulanmıştır [41]. Nitekim bizim çalışmamızda da K iyonu; patlıcanda 
stoma iletkenliği ile, domateste de nispi nem içeriği ile önemli derecede pozitif yönlü bir etkileşimde bulunmuştur.

Kalsiyumun kuraklığa dayanımda önemli bir role sahip olduğu, kuraklık streslerinde kloroplastlarda meydana gelen bozulmaların Ca birikimini azaltabileceği, literatürde yer alan bilgilerden birisidir [61]. Bitkinin bulunduğu ortamdan su alabilmesi için hücre içindeki ozmotik potansiyelin, dış ortamdan yüksek olması gerekmektedir. Bitkiler bunu sağlayabilmek için kökleri yardımıyla yetiştikleri ortamdan inorganik iyonları almaktadırlar. Strese bağlı olarak bitkilerde Ca içeriğinde azalma meydana geldiği bilinmektedir [15]. Çalı̧mamızda skala, yaprak su potansiyeli ve klorofil içeriği ile pozitif yönde korelasyon gösteren bulgularımız, önceki çalışmalarda yer alan [5-18] bulgular ile de paralellik göstermektedir.

Bitkilerde demir ile birlikte klorofil oluşumuna yardım eden ve fotosentez için gerekli olan manganez elementinin, kuraklık koşulları altında bitkilerdeki birikimi azalmaktadır. Çalışmamızda Mn iyonu; patlıcan ve kavun genotiplerinde $\mathrm{Ca}$ içeriği ile pozitif bir ilişi içerisinde yer almış olup bu sonuçlar başka bazı çalışma sonuçlarıyla [50-56] paralellik göstermektedir.

Demir, abiyotik stres koşullarında azalma gösteren iyonlardan birisidir. Araştırmamızda kuraklık stresi uygulanan patlıcan, domates ve kavun türlerine ait tüm genotiplerin demir içeriğinde azalma görülmüş, kavun ve domateste yaprak su potansiyeli ile önemli düzeyde ve olumsuz yönde gösterdiği korelasyon dikkat çekici bulunmuştur. Nitekim literatürde kurak koşullarda Fe miktarının azaldığı [15- 50], kuraklık stresi altında yaprak su potansiyeli azalan nohut ve mercimek bitkilerinin Fe iyonunda da azalma görülebileceği [19] ifade edilmektedir.

Kuraklık koşulları kavun, patlıcan ve domateste diğer iyonlarda olduğu gibi Zn iyonunun alımını da olumsuz yönde etkilemiştir. Stres sonucunda patlıcan ve kavun genotiplerinde belirlenen $\mathrm{Zn}$ miktarının; yaprak su potansiyeli ve Ca miktarı ile olan ilişkisi önemli bulunmuştur. Elde ettiğimiz bulgular, mısır [24] ve fasulyede [60] yapılan önceki çalışmaların sonuçları ile benzerlik göstermektedir.

Kuraklık stresinin diğer bir etkisi ise hücre çeperlerinde meydana gelen zararlanmadır. Lipid peroksidasyonunun bir ürünü olan malondialdehit (MDA) içeriği, kuraklık stresinden kaynaklanan oksidatif hasarın bir göstergesi olarak, stres uygulamasından itibaren denemede yer alan üç türe ait tüm genotiplerin yaprak dokularında artış göstermiş ve skala değerleri ile önemli ve pozitif yönde bir korelasyon göstermiştir. Genotiplerin kuraklık karşısında oluşturduğu tepkiler MDA değişimi üzerinde etkili olmuştur. Domateste [20], kavunda [34], buğdayda [49], patlıcanda [27] yapılan çalışmalarda, kuraklık stresi uygulanan bitkilerin yapraklarında MDA miktarının kontrol bitkilerine göre önemli seviyede yüksek bulunduğu, stresten etkilenen yüksek skala değerine sahip hassas genotiplerde daha yüksek MDA biriktiği saptanmıştır. Domates, patlıcan ve kavun türlerinde gerçekleştirilen bu çalışmada da artan skala değerleriyle pozitif yönde bir ilişki içerisinde olmak üzere, MDA miktarında da artışlar meydana gelmiştir.

Bitkilerin diğer birçok stres faktöründe olduğu gibi kuraklık stresinde de farklı mekanizmalar eşliğinde savunma mekanizmalarını çalıştırması çeşitli araştırmalar sonucunda ortaya konmuştur. Kuraklık stresi sonucunda oluşan ve yüksek düzeylere ulaşan ROS (Reactive oxygene species)'u zararsız bileşiklere dönüştüren antioksidant enzim aktiviteleri, bitkilerde oksidatif strese karşı etkili olan en önemli dayanım mekanizmaları olarak işlev görmektedir [25]. Süper oksit dismutaz (SOD), katalaz (CAT), glutatyon redüktaz (GR), askorbat peroksidaz (APX) gibi enzimler, etkin antioksidatif enzimler arasında yer almaktadır. Kuraklık stresi koşullarında SOD, CAT, GR, APX enzim aktiviteleri uyarılmaktadır $[39,7,16]$. Sonuçları verilen ve üç türde 
yürütmüş olduğumuz bu çalışmada da stres faktörü ve zararlanmaya bağlı olarak SOD, GR, APX ve CAT gibi enzim aktivitelerinde artışlar meydana gelmiştir. Bu artışlar değişen oranlarda olmakla birlikte; domateste ve patlıcanda CAT ile GR enzim aktiviteleri arasında, kavunda ve domateste ise GR ile SOD enzim aktiviteleri arasında yüksek bir korelasyon belirlenmiştir. Araştırıcılar mısırda [40], bezelyede [7], buğdayda [13] kuraklık stresi sonucu SOD ve CAT enzim aktivitelerinde artış meydana geldiğini belirlemişlerdir. Kuraklık stresi uygulamaları karşısında genotiplerin CAT ve GR enzim aktivitelerini artırmak suretiyle oksidatif stresin olumsuz etkisinden kendilerini koruyabildikleri ileri sürülmektedir [22-39-7]. Sonuçları sunulan bu araştırmada, kavun genotiplerinin APX enzim aktivitesinin SOD, CAT ve GR enzim aktiviteleri ile de önemli düzeyde korelasyon gösterdiği anlaşılmıştır. Nitekim kuraklık stresi koşullarında SOD, CAT ve GR enzim aktivitesi yanı sıra APX enzim aktivasyonunun da artış gösterdiği önceki çalışmalarda ortaya konmuştur [42-50-28-23]. Kaynaklarda, enzim aktivasyonundaki artışların genotiplerin kurağa toleransı oluşturmasında etkin bir rolü olabileceğine dikkat çekilmektedir.

Domates, patlıcan ve kavun genotiplerinin kuraklığa karşı gösterdikleri morfolojik, fizyolojik ve biyokimyasal tepkilerin kendi aralarındaki ilişkilerin incelendiği bu çalışmada; skala değerlendirmesinin diğer tüm özellikler ile ilişkili olan önemli bir parametre niteliği ile ön plana çıktığı söylenebilir. Skala değeri ile bitki yaş ağırlığı, yaprak alanı, yaprak su potansiyeli, stoma iletkenliği, K ve MDA içeriği değerlerinin yanı sıra antioksidatif enzim aktivitelerinin de diğer fizyolojik ve morfolojik karakterlerle ile birlikte domates, patlıcan ve kavun genotiplerinde kuraklık stresine tolerans özelliği üzerinde etkili birer kriter olarak değerlendirilebileceği sonucuna varılmıştır.

\section{Kaynaklar}

[1] Ahmadizadeh, M. 2013. Physiological and agro-morphological response to drought stress. Middle-East Journal of Scientific Research 13 (8): 998-1009.

[2] Alexieva, V., Sergiev, I., Mapelli, S., Karanov, E. 2001. The effect of drought ultraviolet radiation on growth and stress markers in pea and wheat. Plant, Cell and Environment 24 (12): 1337-1344.

[3] Anjum, S.A., Xie, X., Wang, L., Saleem, M.F., Man, C, Lei, W. 2011. Morphological, physiological and biochemical responses of plants to drought stress. African Journal of Agricultural Research 6 (9): 2026-2032.

[4] Anonymous. 2014. Türkiye İstatistik Kurumu http://tuikrapor.tuik.gov.tr/reports

[5] Arjenaki, F.G., Jabbari, R., Morshedi A. 2012. Evaluation of drought stress on relative water content, chlorophyll content and mineral elements of wheat (Triticum aestivum L.) varieties. Intl J Agri Crop Sci. 4 (11): 726-729.

[6] Ashraf, M., Iram, A. 2005. Drought stress induced changes in some organic substances in nodules and other plant parts of two potential legumes differing in salt tolerance. Flora 200: 535-546.

[7] Bahadur, A, Chatterjee, A., Kumar, R., Singh, M., Naik, Ps. 2011. Physiological and biochemical basis of drought tolerance in vegetables. Vegetable Science 38 (1): 1-16.

[8] Beroval, M., Stoilova, T., Kuzmoval, K., Stoeval, N., Vassilevl, A., Zlatevl, Z. 2012. Changes in the leaf gas exchange, leaf water potential and seed yield of cowpea plants (Vigna unguiculata L.) under 
soil drought conditions. Ed. By Agricultural University, Plovdiv, Agricultural Sciences, vol. IV/8: 2934.

[9] Capell, T., Bassie, L., Christou, P. 2004. Modulation of the polyamine biosynthetic pathway in transgenic rice confers tolerance to drought stress, Pnas, 101 (26): 9909-9914.

[10] Costa França, M.G., Pham-Thi, C.A.T., Pimentel, R.O.P., Rossiello, Y., Fodil, Z., Laffray, D. 2000. Differences in growth and water relations among Phaseolus vulgaris cultivars in response to induced drought stress. Environ. Exp. Bot. 43 (3): 227-237.

[11] Çakmak, I., Marschner, H. 1992. Magnesium deficiency and highlight intensity enhance activities of superoxide dismutase, ascorbate peroxidase and glutathione reductase in bean leaves. Plant Physiol. 98 (4): $1222-1226$.

[12] Çakmak., I. 1994. Activity of ascorbate-dependent $\mathrm{H}_{2} \mathrm{O}_{2}$ scavenging enzymes and leaf chlorosis are enhanced in magnesium and potassium deficient leaves, but not in phosphorus deficient leaves. J. Exp. Bot. 45 (278): 1259-1266.

[13] Chakraborty, U., Pradhan, B. 2012. Oxidative stress in five wheat varieties (Triticum aestivum L.) exposed to water stress and study of their antioxidant enzyme defense system, water stress responsive metabolites and $\mathrm{H}_{2} \mathrm{O}_{2}$ accumulation. Braz. J. Plant Physiol. 24 (2): 117-130.

[14] Doğan, M. 2003. Domates (Lycopersicon sp.)'te Tuz Stresinin Bazı Fizyolojik Parametreler ve Antioksidant Enzim Aktiviteleri Üzerine Etkileri. Doktora Tezi. Hacettepe Üniv. Fen Bilimleri Enstitüsü, 89s, Ankara.

[15] Doğan, N. 2006. Su Stresi Altındaki Fasulye (Phaseolus vulgaris L.) Bitkisinin İyon Alım Mekanizmasının Araştııılması. Y. Lisans Tezi. Marmara Üniv. Fen Bilimleri Enst., İstanbul.

[16] Fghire, R., Issaali, O., Anaya, F., Benlhabib, O., Jacobsen, S.E., Wahbi, S. 2013. Protective antioxidant enzyme activities are affected by drought in quinoa (Chenopodium quinoa Willd). Journal of Biology, Agriculture and Healthcare 3 (4): 62-68.

[17] Freed, R., Einensmith, S.P., Guets, S., Reicosky, D., Smail, V.W., Wolberg, P. 1989. User's guide to MSTAT-C, an analysis of agronomic research experiment. Michigan State University, USA.

[18] Saruhan Güler, N., Sağlam, A., Demiralay, M., Kadığlu, A. 2012. Apoplastic and symplastic solute concentrations contribute to osmotic adjustment in bean genotypes during drought stress. Turk J Biol. 36: $151-160$.

[19] Güneş,A. 2006. Mercimek ve Nohut Bitkilerinde Kuraklı̆ga Bağlı Oksidatif Stres ve Fizyolojik Tolerans Mekanizmalarının Belirlenmesi. A.Ü. Bilimsel Araştırma Projesi Kesin Raporu.

[20] Giannakoula, A.E., Ilias, I.F. 2013. The effect of water stress and salinity on growth and physiology of tomato (Lycopersicon esculentum Mill.). Arch. Biol. Sci., Belgrade 65 (2): 611-620.

[21] Hajibabaee, M., Azizi, F., Zargari, K. 2012. Effect of drought stress on some morphological, physiological and agronomic traits in various foliage corn hybrids. American-Eurasian J. Agric. \& Environ. Sci. 12 (7): 890-896.

[22] van Heerden, P.D., Krüger, G.H.J. 2002. Separately and simultaneously induced dark chilling and drought stress effects on photosynthesis, proline accumulation and antioxidant metabolism in soybean. $J$ Plant Physiol. 159: 1077-1086. 
[23] Hosseini, M.S., Hasanloo, T., Mohammadi, S. 2014. Physiological characteristics, antioxidant enzyme activities, and gene expression in 2 spring canola (Brassica napus L.) cultivars under drought stress conditions. Turkish Journal of Agriculture and Forestry 38: 1-8.

[24] Hu Y., Burucs, Z., Tucher, S., Schmidhalter, U. 2007. Short-term effects of drought and salinity on mineral nutrient distribution along growing leaves of maize seedlings. Environmental and Experimental Botany 60: 268-275.

[25] Huang, C., Zhao, S., Wang, L., Anjum, S.A., Chen, M., Zhou, H., Zou, C. 2013. Alteration in chlorophyll fluorescence, lipid peroxidation and antioxidant enzymes activities in hybrid ramie (Boehmeria nivea L.) under drought stress. Australian Journal of Crop Science 7 (5): 594-599.

[26] Jaleel, C.A., Manivannan, P., Sankar, B., Kishorekumar, A., Gopi, R., Somasundaram, R., Panneerselvam, R. 2007. Water deficit stress mitigation by calcium chloride in Catharanthus roseus: Effects on oxidative stress, proline metabolism and indole alkaloid accumulation. Biointerfaces 60: 110116.

[27] Jifeng, D., Shiqi, L., Zikun, Z., Hui, W., Jianjian, Q. 2009. Effect of drought stress on physiological and biochemical indexes of Nigeria eggplant. Chinese Agricultural Science Bulletin 4: 187-190.

[28] Kavas, M., Baloğlu, M.C., Akça, O., Köse, F.S., Gökçay, D. 2013. Effect of drought stress on oxidative damage and antioxidant enzyme activity in melon seedlings. Turkish Journal of Biology 37: 491-498.

[29] Kırnak, H., Kaya, C., Taş, I., Higgs, D. 2001. The influence of water deficit on vegetative growth, physiology, fruit yield and qualty. Bulg. J. Plant Physiol. 27 (3-4): 34-46.

[30] Kocaçalışkan, İ. 2003. Bitki Fizyolojisi. DPÜ Fen-Edebiyat Fakültesi Yayını, 420 s.

[31] Kuşvuran, Ş., Ellialtıŏlu, S., Abak, K., Yasar, F. 2007. Responses of Some Melon (Cucumis Sp.) Genotypes to Salt Stress. Journal of Agricultural Sciences, Ankara University Faculty of Agriculture 13 (4): 395-404.

[32] Kuşvuran, Ş., Daşgan, H.Y., Abak, K. 2008. Farklı Bamya Genotiplerinin Kuraklık Stresine Tepkileri. VII. Sebze Tarımı Sempozyumu, 26-29 Ağustos 2008, Yalova.

[33] Kuşvuran, Ş., Küçükkömürcü, S., Daşgan, H.Y., Abak, K. 2009. Relationships between drought tolerance and stomata density in melon. The 4th International Cucurbitaceae Symposium, 20-24 September, China.

[34] Kuşvuran, Ş. 2010. Kavunlarda Kuraklık ve Tuzluluğa Toleransın Fizyolojik Mekanizmaları Arasındaki Bağlantılar. Çukurova Üniversitesi Fen Bilimleri Enst., Doktora Tezi, 355 s., Adana.

[35] Kuşvuran, Ş. 2012. Effects of drought and salt stresses on growth stomatal conductance leaf water and osmotic potentials of melon genotypes (Cucumis melo L.). African Journal of Agricultural Research 7 (5): 775-781.

[36] Luna, C., Seffino, L.G., Arias, C., Taleisnik, E. 2000. Oxidative stress indicators as selection tools for salt tolerance in Chloris gayana. Plant Breeding 119: 341-345.

[37] Lutts, S., Kinet, J.M., Bouharmont, J. 1996. NaCl-Induced senesence in leaves of rice (Oryza sativa L.) cultivars differing in salinity resistance. Ann. Bot. 78: 389-398.

[38] Mehri, N., Fotovat, R., Saba, J., Jabbari, F. 2009. Variation of stomata dimensions and densities in tolerant and susceptible wheat cultivars under drought stres. Journal of Food Agriculture and Environment 7 (1): 167-170. 
[39] Mohammadkhani, N., Heidari, R. 2007. Effects of drought strees on protectiv enzyme activities and lipid peroxidation in two maize cultivars. Pakistan Journal of Biological Sciences 10 (2): 3835-3840.

[40] Moussa, H.R., Abdel-Aziz, S.M. 2008. Comparative response of drought tolerant and drought sensitive maize genotypes to water stress. Australian Journal of Crop Science 1 (1): 31-36.

[41] Nasri, M., Zahedi, H., Moghadam, H.R.T., Ghooshci, F., Paknejad, F. 2008. Investigation of water stress on macro elements in rapeseed genotypes leaf (Brassica napus). American Journal of Agricultural and Biological Sciences 3 (4): 669-672.

[42] Nikolaeva, M.K., Maevskaya, S.N., Shugaev, A.G., Bukhov, N.G. 2010. Effect of drought on chlorophyll content and antioxidant enzyme activities in leaves of three wheat cultivars varying in productivity. Russian Journal of Plant Physiology 57 (1): 87-95.

[43] Oliveira Neto, C.F., Silva Lobato, A.K., Gonçalves-Vidigal, M.C., Lobo Da Costa, R.C., Santos Filho, B.G., Ruffeil Alves, G.A., Silva Maia, W.J.M., Rodrigues Cruz, F.J., Borges Neves, H.K., Santos Lopes, M.J. 2009. Carbon compounds and chlorophyll contents in sorghum submitted to water deficit during three growth stages. Journal of Food, Agriculture \& Environment 7 (3\&4): 588-593.

[44] Özcan S., Babaoğlu, M., Gürel, E. 2004. Bitki Biyoteknolojisi Genetik Mühendisliği ve Uygulamaları, S.Ü. Vakfi Yayınları, Konya.

[45] Ramírez-Builes, V.H. 2007. Plant-Water Relationships for Several Common Bean Genotypes (Phaseolus vulgaris L.) With and Without Drought Stress Conditions. M.Sc. Thesis University of Puerto Rico, 190 pp.

[46] Reddy, A.R., Chaitanya, K.V., Jutur, P.P., Sumithra, K. 2004. Differential antioxidative responses to water stress among five mulberry (Morus alba L.) cultivars. Environmental and Experimental Botany 52: $33-42$.

[47] Rezene, Y., Gebeyehu, S., Zelleke, H. 2013. Morpho-physiological response to post-flowering drought stress in small red seeded common bean (Phaseolus vulgaris L.) genotypes. Journal of Plant Studies 2(1): $36-41$

[48] Romanello, G.A., Chuchra-Zbytniuk, K.L., Vandermer, J.L., Touchette B.W. 2008. Morphological adjustments promote drought avoidance in the wetland plant Acorus americanus. Aquatic Botany 89: 390-396.

[49] Rustamova, S.M., Babayev, H.H., Husynova, I.M. 2013. Antioxidant defence system and chloroplasts photochemical characteristics of wheat genotypes subjected to water stress. Photosynhesis Research for Food, Fuel and the Future Advanced Topics in Science and Technology in China, pp 568-571.

[50] Sánchez-Rodriguez, E., Rubio-Wilhelmi, M.M., Cervilla, L.M., Blasco, B., Rios, J., Rosales, M.A., Romero, L., Ruiz, J.M. 2010. Genotypic differences in some physiological parameters symptomatic for oxidative stress under moderate drought in tomato plants. Plant Science 178: 30-40.

[51] Sevengör, S., Yasar, F., Kusvuran, S., Ellialtioglu, S. 2011. The effect of salt stress on growth, chlorophyll content, lipid peroxidation and antioxidative enzymes of pumpkin seedling. African J. of Agricultural Research 6(21): 4920-4924.

[52] Sivritepe, N., Erturk, U., Yerlikaya, C., Türkan, I., Bor, M., Özdemir, F. 2008. Response of the cherry rootstock to water stress induced in vitro. Biologia Plantarum 52 (3): 573-576.

[53] Shamim, F., Rehman Athar, H., Waheed, A. 2013. Role of osmolytes in degree of water stress tolerance in tomato. Pak. J. Phytopathol. 25 (1): 37-42. 
[54] Stagnari, F., Galieni, A., Speca, S., Pisante, M. 2014. Water stress effects on growth, yield and quality traits of red beet. Scientia Horticulturae 165: 13-22.

[55] Taleisnik, E., Peyrano, G., Arias, C. 1997. Respose of Chloris gayana cultivars to salinity. 1. Germination and early vegetatif growth. Trop. Grassl. 31: 232-240.

[56] Thiec, D.L., Manninen, S. 2003. Ozone and water deficit reduced growth of Aleppo pine seedling. Plant Physiology and Biochemistry 41: 55-63.

[57] Türkan, I., Bor, M., Özdemir, F., Koca, H. 2005. Differential responses of lipid peroxidation and antioxidants in the leaves of drought-tolerant $P$. acutifolius Gray. and drought sensitive P. vulgaris L. subjected to polyethylene glycol mediates water stress. Plant Science 168: 223-231.

[58] Yaşar, F. 2003. Tuz Stresi Altındaki Patlıcan Genotiplerinde Bazı Antioksidant Enzim Aktivitelerinin in vitro ve in vivo Olarak İncelenmesi. Yüzüncü Yıl Üniversitesi Fen Bilimleri Enstitüsü, Doktora Tezi, 139 s., Van.

[59] Yaşar, F., Kuşvuran, Ş., Ellialtıoğlu, Ş., 2006. Determination of anti-oxidant activities in soma melon (Cucumis melo L.) varieties and cultivars under salt stress. Journal of Horticultural Science \& Biotechnology 81 (4): 627-630.

[60] Yasar, F., Uzal, Ö., Yasar, Ö., Ellialtioglu, Ş.Ş. 2014. Root, stem, and leaf ion accumulation in drought stressed green bean (Phaseolus vulgaris L.) genotypes treated with Peg-6000. Fresenius Environmental Bulletin 23 (10a): 2656-2662.

[61] Yuan-Yuan, M., Wei-Yi, S., Zi-Hui, L., Hong-Mei ,Z., Xiu-Lin ,G., Hong-Bo, S., Fu-Tai, N. 2009. The dynamic changing of $\mathrm{Ca}^{2+}$ cellular localization in maize leaflets under drought stress. $C$. R. Biologies 332: $351-362$.

[62] Yurtsever, N. 2011. Deneysel İstatistik Metotlar. Toprak Gübre ve Su Kaynaklarl Merkez Araştırma Enstitüsü Yayınları. 2.Baskı, Ankara. 